\title{
Study of Transuranium Recycling in PWR with 3-D Burnup Analysis using SRAC-COREBN Code
}

\author{
Abdul Waris ${ }^{1), *}$, T. Rahmanto ${ }^{2)}$, Imam Taufiq ${ }^{1)}$, Rizal Kurniadi ${ }^{1)}$, and Zaki Su'ud ${ }^{1)}$ \\ 1) Nuclear Physics and Biophysics Research Division \\ Faculty of Mathematics and Natural Sciences \\ ${ }^{2)}$ Department of Engineering Physics \\ Faculty of Industrial Technology \\ Institut Teknologi Bandung, INDONESIA \\ *e-mail: awaris@fi.itb.ac.id
}

\begin{abstract}
In the light of proliferation resistance and terrorism issues several nuclear energy authorities and experts have suggested not to separate plutonium and minor actinides during the nuclear spent fuel reprocessing. Along the lines of this recommendation, a study of transuranium recycling in pressurized water reactor (PWR) with 3 dimensional burnup analysis by using SRAC-COREBN code has been carried out. The results show that by recycling of 8\%, $10 \%$, and $12 \%$ of plutonium and minor actinides in PWR, the necessary uranium enrichment in loaded enriched uranium fuel of each scenario can be reduced to $2.7 \%, 1.52 \%$, and $1.32 \%$, correspondingly. In addition to this, the amount of loaded uranium fuel diminishes considerably with the increasing of the amount of recycled of plutonium and minor actinides.
\end{abstract}

Keywords: PWR, Plutonium, Minor Actinides, SRAC-COREBN Code, Burnup Analysis

\section{Introduction}

Plutonium is one of the important elements in the nuclear industry beside uranium, thorium and minor actinides (MA). It is a most prominent source of toxicity and also an excellent fissile material in the nuclear spent fuel. Therefore, transmutation of plutonium by recycling it in a nuclear reactor or other nuclear energy system has two important merits those are to gain energy and at the some time to eliminate the toxicity ${ }^{1,2)}$. Study on recycling of plutonium in the nuclear reactor has been started from 1970s and became very intensive during the middle of 1990s, especially in Japan, UK, and France ${ }^{3)}$.

In the light of proliferation resistance and terrorism issues several nuclear energy authorities and experts have recommended to not to separate plutonium and minor actinides during the nuclear spent fuel reprocessing ${ }^{4)}$. In line with this suggestion the authors have started earlier to study the recycling of plutonium together with minor actinides ${ }^{5-9}$. However, these previous studies were performed in the cell-calculation level that is in 1-dimension or 2dimension of reactor core geometry. The 3dimensional evaluation of plutonium and minor actinides recycling in pressurized water reactor (PWR) has been conducted, but still restricted to homogeneous core ${ }^{10}$. Therefore, the objective of the present study is to evaluate the trans-uranium (TRU) especially plutonium and MA recycling in PWR with 3-dimentional burnup analysis.

\section{Methodology}

In this study, the burnup calculation was performed at the full scale of 3-D reactor core through solving multi-group neutron diffusion equation with finite difference method that provided by SRACCOREBN code ${ }^{11)}$. While calculation of macroscopic cross-section by collision probability method performed by SRAC-PIJ code ${ }^{12)}$. Nuclear data that have been employed in this calculation were generated from JENDL $3.2^{13)}$.

Figure 1 shows the flow of material in the recycling process. At the beginning, plutonium is mixed with minor actinides extracted from spent fuel that has been cooled for about three years before reprocessing process at the reprocessing plant. Next, those materials are fabricated as a new fuel and then are loaded in the reactor together with fresh enriched uranium fuel so the reactor can reach its critical condition. In this condition recycling process is conducted once.

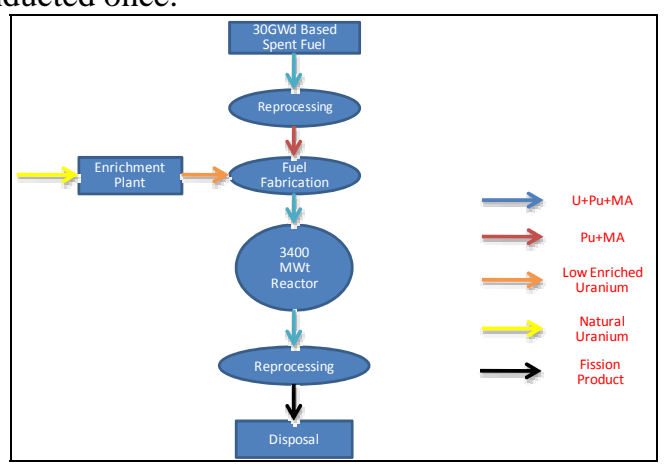

Figure 1. Flow of nuclear materials during recycling process

The reactor used for the recycling are PWR type nuclear reactor manufactured by Westinghouse, which produce $1150 \mathrm{MW}$ electric power and using Zircalloy- 
4 for its cladding material. Detailed specification of this reactor can be seen in the Table 1 below ${ }^{14)}$. Table 1. Reactor Specification

\begin{tabular}{|l|r|}
\hline Thermal output (MWt) & 3400 \\
\hline Fuel weight (kg) & 94676.9 \\
\hline Burnup (GWD/MTU) & 40.0 \\
\hline Number of assemblies & 193 \\
\hline Fuel element array & $17 \times 17$ \\
\hline Assembly dimension & $21.4 \times 21.4$ \\
\hline Fuel pellet diameter $(\mathrm{cm})$ & 0.819 \\
\hline Average linear power density $(\mathrm{W} / \mathrm{cm})$ & 178 \\
\hline
\end{tabular}

The plutonium and minor actinides isotopic composition that have been employed in the present study are tabulated in Table 2, which based on the References $^{15)}$ and ${ }^{16)}$, respectively.

Table 2. Isotopic composition of recycled Pu \& MA

\begin{tabular}{|l|r|}
\hline \multicolumn{2}{|c|}{ Plutonium } \\
\hline $\mathrm{Pu}-238$ & $1.81 \%$ \\
\hline $\mathrm{Pu}-239$ & $59.14 \%$ \\
\hline $\mathrm{Pu}-240$ & $22.96 \%$ \\
\hline $\mathrm{Pu}-241$ & $12.13 \%$ \\
\hline $\mathrm{Pu}-242$ & $3.96 \%$ \\
\hline
\end{tabular}

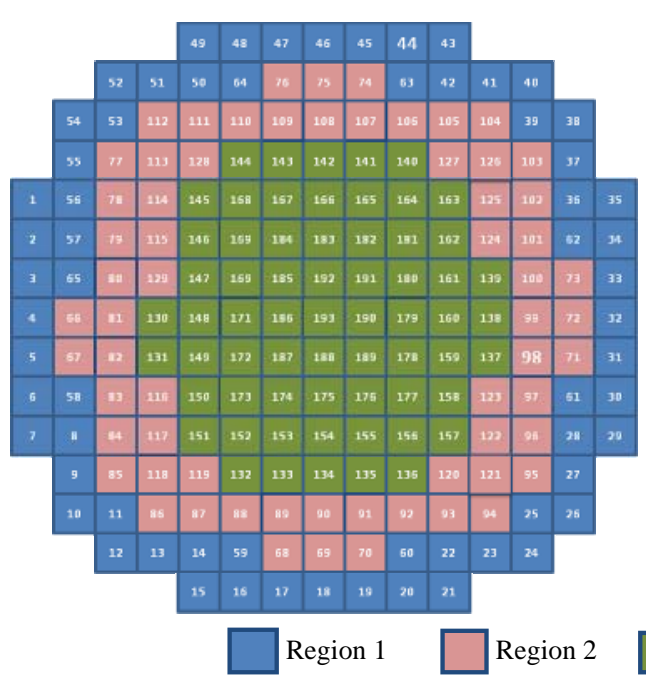

Figure 2. Fuel Assemblies arrangement in the core

Effective multiplication factor ( $k$-eff) of cell calculation by using SRAC-PIJ code is given in Figure 3. The cycle length of reactor operation time is 3 years. As can be seen in this figure, $k$-eff value is higher than unity for the whole cycle length, which means that reactor can achieve its criticality condition during operation time. In this figure, the k-eff for $6 \%$ and $14 \%$ of plutonium and minor actinides in loaded fuel are also presented for comparison.

\begin{tabular}{|l|r|}
\hline \multicolumn{2}{|c|}{ Minor Actinides } \\
\hline Np-237 & $16.67 \%$ \\
\hline Am-241 & $52.05 \%$ \\
\hline Am-242m & $1.51 \%$ \\
\hline Am-243 & $29.23 \%$ \\
\hline Cm-245 & $0.54 \%$ \\
\hline
\end{tabular}

\section{Result and Discussion}

The geometry of PWR core and the arrangement of fuel assemblies in the core are given in the following Figure 2. Three recycling scenario have been evaluated. Those are $8 \%, 10 \%$ and $12 \%$ of total plutonium and MA concentration in the whole core. The rest composition is the enriched uranium fuel. In standard operation of PWR with only enriched uranium as the fuel, the required uranium concentration in the fuel ranges between $3.1-3.5 \%$. One of the aims of the present study is to evaluate whether the required enrichment in loaded uranium fuel can be reduced by recycling of plutonium and MA.

\begin{tabular}{|c|c|}
\hline \multirow{2}{*}{ Recycling Scenario } & $\begin{array}{c}\text { Pu \&MA Concentration in } \\
\text { Fuel Assembly }\end{array}$ \\
\hline \multirow{3}{*}{$8 \% \mathrm{Pu}+\mathrm{MA}$} & $10 \% \mathrm{Pu}+\mathrm{MA}$ \\
\cline { 2 - 2 } & $8 \% \mathrm{Pu}+\mathrm{MA}$ \\
\cline { 2 - 2 } & $6 \% \mathrm{Pu}+\mathrm{MA}$ \\
\hline \multirow{3}{*}{$10 \% \mathrm{Pu}+\mathrm{MA}$} & $12 \% \mathrm{Pu}+\mathrm{MA}$ \\
\cline { 2 - 2 } & $10 \% \mathrm{Pu}+\mathrm{MA}$ \\
\cline { 2 - 2 } & $8 \% \mathrm{Pu}+\mathrm{MA}$ \\
\hline \multirow{2}{*}{$12 \% \mathrm{Pu}+\mathrm{MA}$} & $14 \% \mathrm{Pu}+\mathrm{MA}$ \\
\cline { 2 - 2 } & $12 \% \mathrm{Pu}+\mathrm{MA}$ \\
\cline { 2 - 2 } & $10 \% \mathrm{Pu}+\mathrm{MA}$ \\
\hline
\end{tabular}

Region 3

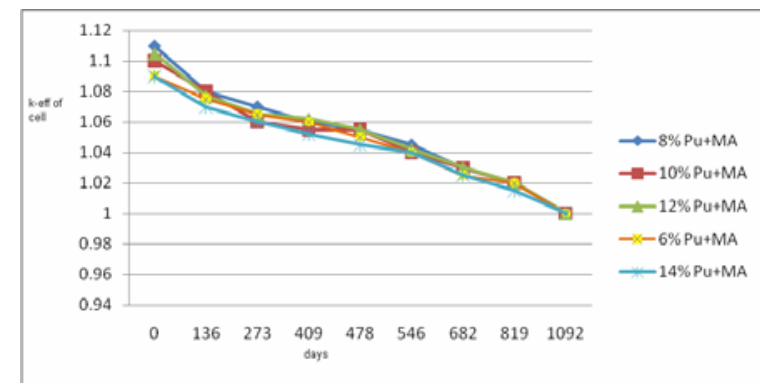

Figure 3. Effective multiplication factor of cell calculation 
Figure 4 shows the effective multiplication factor of whole core (3-D) calculation by using SRAC-COREBN code. As in Figure 3, k-eff value is upper than one, and PWR can accomplish its criticality condition for the whole cycle length. These results also show the consistency of both cell calculation and 3-D burnup calculation.

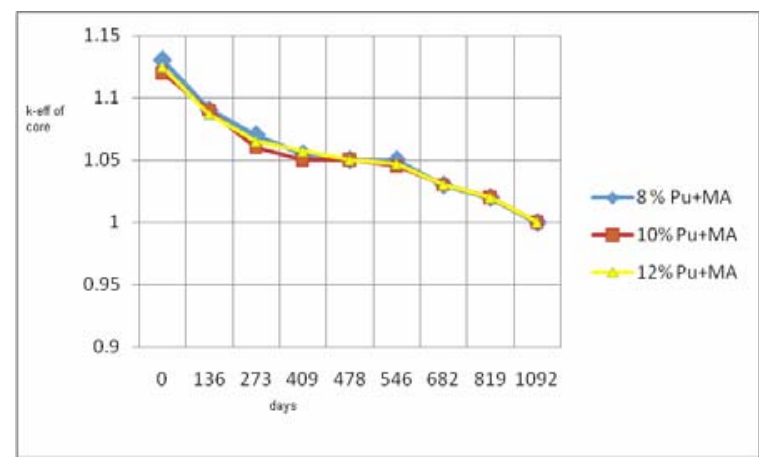

Figure 4. Effective multiplication factor of whole core calculation

Table 3 presents the composition of loaded fuel for each scenario. By recycling of $\mathrm{Pu}$ and MA the required uranium enrichment in loaded enriched uranium fuel of each scenario can be reduced to $2.7 \%$, $1.52 \%$, and $1.32 \%$, respectively. As a matter of perspective, the required enrichment of uranium for standard PWR without recycling is about 3-1 - 3.5\%. This fact confirmed that plutonium and minor actinides act as new nuclear fuel that can substitute some fraction of loaded uranium fuel during recycling process.

Table 3. Loaded fuel composition of each scenario

\begin{tabular}{|c|c|c|c|}
\hline Scenario & $\begin{array}{c}\text { U-enrichment } \\
(\%)\end{array}$ & $\begin{array}{c}\text { Plutonium } \\
\text { concentration } \\
(\%)\end{array}$ & $\begin{array}{c}\text { MA } \\
\text { concentration } \\
(\%)\end{array}$ \\
\hline I & 2.70 & 7.20 & 0.80 \\
\hline II & 1.52 & 9.02 & 1.00 \\
\hline III & 1.32 & 10.77 & 1.19 \\
\hline
\end{tabular}

Table 4 shows the amount of loaded enriched uranium fuel from natural uranium of each scenario. The amount of loaded uranium fuel decreases significantly with the augmented of the amount of recycled of plutonium and minor actinides in PWR.

Table 4. Amount of loaded enriched uranium fuel of each scenario

\begin{tabular}{|c|c|c|}
\hline \multirow{2}{*}{ Scenario } & $\begin{array}{c}\text { Without } \\
\text { recycling (kg) }\end{array}$ & $\begin{array}{c}\text { With Plutonium \& MA } \\
\text { recycling (kg) }\end{array}$ \\
\hline \multirow{2n}{*}{ I } & \multirow{2}{*}{94676.9} & 83613,79 \\
\cline { 1 - 1 } II & 81818,19 \\
\hline III & & 79992,65 \\
\hline
\end{tabular}

\section{Conclusion}

Study of TRU recycling in PWR with 3-D burnup analysis by using SRAC-COREBN code has been conducted. The results show that by recycling of $8 \%, 10 \%$, and $12 \%$ of plutonium and MA in PWR, the required uranium enrichment in loaded enriched uranium fuel of each scenario can be reduced to $2.7 \%$, $1.52 \%$, and $1.32 \%$, respectively. Moreover, the amount of loaded uranium fuel decreases significantly with the augmenting of the amount of recycled of plutonium and minor actinides.

\section{Acknowledgements}

This research is fully funded by ITB Research Grant No. 240/K01.7/PL/2009.

\section{References}

1. A. Waris, R. Kurniadi, and Z. Su'ud, Plutonium and Minor Actinides Recycling in Standard BWR using Equilibrium Burnup Model, ITB Journal of. Science, 40A:1, 15-23, 2008.

2. A. Waris et al., Influence of void fraction change on Plutonium and Minor Actinides Recycling in BWR with Equilibrium Burnup, Progress of Nuclear Energy, 50:2-6, 295-298, 2008.

3. A. Waris, Study on Charateristics of Equilibrium Fuel Cycles of PWR, Ph. D Dissertation at Department of Nuclear Engineering, Tokyo Institute of Technology, 2002.

4. L. Koch, Proliferation Resistance Aspects in Nuclear Fuel Cycles, Workshop on Role of Partitioning and Transmutation in the Mitigation of The Potential Environmental Impacts of Nuclear Fuel Cycle, ICTP, Trieste, Italy, November 20 -24, 2006.

5. A. Waris and H. Sekimoto, Characteristics of Several Equilibrium Fuel Cycles of PWR, J. Nucl. Sci. Technol., 38: 517, 2001.

6. A. Waris and H. Sekimoto, Basic Study on Characteristics of several equilibrium fuel cycles of PWR, Annals of Nuclear Energy 2001; 28: 153, 2001.

7. A. Waris, H. Sekimoto, and G. Kastchiev, Influence of Moderator-to-Fuel Volume Ratio on $\mathrm{Pu}$ and MA Recycling in Equilibrium Fuel Cycles of PWR. Proc. Int. Conf. On the New Frontiers of Nuclear Technology, PHYSOR 2002, Seoul, Korea, 2002.

8. A. Waris et al., Comparative Study on Plutonium and MA Recycling in Equilibrium Burnup and Standard Burnup of PWR, Proc. Int. Conf. GLOBAL 2005, paper No. 505, Oct 9 -13 2005, Tsukuba, Japan, 2005.

9. A. Waris et al., Study on Equilibrium Characteristics of Thorium-Plutonium-Minor Actinides Mixed Oxides Fuel in PWR, Proc. Int. Conf. on Advances in Nuclear Sciences and Engineering (ICANSE), 3-4 November, 2009, Bandung, Indonesia, 2009. 
10. D. Prayudhatama and A. Waris, Non-Proliferation Nuclear Fuel Cycle by Homogenized Plutonium and Minor Actinide Multiple recycling based on current PWR type Nuclear Power Plant Technologies, Proc. Int.Conf. on Mathematics and Natural Sciences (ICMNS) 2008, Bandung, Indonesia, October, 2008.

11. K. Okumura et al., SRAC-COREBN code System, Japan Atomic Energy Research Institute, Tokaimura, Japan, 2002.

12. K. Okumura et al., SRAC: The Comprehensive neutronics calculation code system, Japan Atomic Energy Research Institute, Tokaimura, Japan, 2002.
13. T. Nakagawa et al., Japanese Evaluated Nuclear Data Library Version 3 Revision-2: JENDL-3.2, J. Nucl. Sci. Technol, 32, 1259, 1996.

14. J.J Duderstadt, L. J. Hamilton, Nuclear Reactor Analysis, $3^{\text {rd }}$ Ed., John Wiley \& Sons, New York, 1976

15. http://www-nds.iaea.or.at/wimsd/burnup.htm, first visited, January 2004.

16. B.D. Murphy, Characteristics of Spent Fuel from Plutonium Disposition Reactor”, Vol. 1, Oak Ridge National Laboratory, ORNL/TM13170/VI, 1996. 